\title{
Budburst and flowering intensity by the spraying of dormancy- breaking products in 'Eva' apple trees
}

\section{Brotação e intensidade de floração pela aplicação de indutores de brotação em macieiras 'Eva'}

\author{
Daniel Chamorro Darde ${ }^{1 *}$; Gustavo Klamer de Almeida ${ }^{2}$; \\ Gilmar Arduino Bettio Marodin ${ }^{3}$
}

\begin{abstract}
Spraying of dormancy-breaking chemicals is a mandatory procedure to produce temperate fruits in low-chill regions. Although hydrogen cyanamide (HC) + mineral oil (MO) show efficiency enhancing budburst, the usage of $\mathrm{HC}$ is restricted in some countries due to its toxicity. Therefore, this research aimed to evaluate the efficiency of spraying different dormancy-breaking agents on 'Eva' apple tree buds, under the conditions of the Depressão Central of Rio Grande do Sul, Brazil. Different doses of $\operatorname{Erger}^{\circledR}(0,2,3,4,5 \%)+3 \% \mathrm{Ca}\left(\mathrm{NO}_{3}\right)_{2}$ were tested and compared with $\mathrm{MO}(4 \%)$ or $\mathrm{MO}(4 \%)+$ HC $(0.6 \%)$. Budburst rate of apical and axillary buds, physiological alterations in buds, return bloom, yield and fruit weight were evaluated. Erger $^{\circledR}$ treatments efficiently enhanced budburst, with a result equivalent to $\mathrm{HC}+\mathrm{MO}$ treatment. The budburst rate increased as the $\operatorname{Erger}^{\mathbb{B}}$ dose increased, also causing the increment of the return bloom in the following year. However, doses of 4 and $5 \%$ caused the death of shoots. The activity of the peroxidases and the content of $\mathrm{H}_{2} \mathrm{O}_{2}$ in the buds were affected by the treatments. Yield and fruit mass were different in response to treatments, although the effect varied between years. Erger ${ }^{\circledR}+\mathrm{Ca}\left(\mathrm{NO}_{3}\right)_{2}$ spraying increase budburst in apical and axillary buds of 'Eva' apple tree in low-chill conditions and doses up to $3 \%$ of the commercial product do not cause toxicity.

Key words: Dormancy. Hydrogen peroxide. Malus domestica. Peroxidases. Return bloom.
\end{abstract}

\section{Resumo}

A aplicação de indutores de brotação é uma prática fundamental para a produção de frutíferas temperadas em regiões com menor quantidade de horas de frio. Apesar de cianamida hidrogena $(\mathrm{CH})+$ óleo mineral $(\mathrm{OM})$ apresentarem eficiência na indução da brotação de gemas de macieira, a toxicidade de $\mathrm{CH}$ ao aplicador resultou em restrições ao seu uso em alguns países. Assim, o objetivo do trabalho foi avaliar a eficiência da aplicação de diferentes indutores de brotação de gemas na macieira 'Eva', nas condições da Depressão Central do RS. Testaram-se diferentes doses de $\operatorname{Erger}^{\circledR}(0,2,3,4,5 \%)+3 \% \mathrm{Ca}\left(\mathrm{NO}_{3}\right)_{2}$, comparados com OM (4\%) ou OM (4\%) + CH (0,6\%). Foram avaliados a taxa de brotação de gemas apicais e axilares, alterações fisiológicas nas gemas, o retorno floral, a produção e a massa dos frutos. Os tratamentos de Erger ${ }^{\circledR}$ foram eficientes em aumentar a brotação de gemas, com resultados equivalentes ao tratamento $\mathrm{CH}+\mathrm{OM}$. A taxa de brotação de gemas aumentou em resposta ao aumento na dose de Erger $^{\circledR}$, provocando também incremento no retorno floral no ano seguinte, no entanto doses de 4 e $5 \%$ provocaram morte de ramos. A atividade de peroxidases e os teores de peróxidos de hidrogênio nas

${ }^{1}$ Eng $^{\circ}$ Agr $^{\circ}$, M.e, Universidade Federal do Rio Grande do Sul, UFRGS, Porto Alegre, RS, Brasil. E-mail: danieldarde@gmail.com

2 Eng ${ }^{\circ}$ Agr $^{\circ}$, Dr., UFRGS, Porto Alegre, RS, Brasil. E-mail: gklalmeida@hotmail.com

3 Eng $^{\circ}$ Agr ${ }^{\circ}$, Prof. Dr., UFRGS, Porto Alegre, RS, Brasil. E-mail: marodin@ufrgs.br

Author for correspondence 
gemas apicais foram afetadas pelos tratamentos. A produção e a massa média dos frutos diferiram entre tratamentos, porém o efeito variou entre as safras. A aplicação de $\operatorname{Erger}^{\circledR}+\mathrm{Ca}\left(\mathrm{NO}_{3}\right)_{2}$ aumenta a brotação de gemas apicais e axilares em macieiras 'Eva' em condição de baixo acúmulo de frio e doses de até 3\% do produto comercial não causam toxidez.

Palavras-chave: Dormência. Peróxido de hidrogênio. Malus domestica. Peroxidases. Retorno floral.

\section{Introduction}

The apple tree (Malus domestica Borkh.), a species of temperate climate, shows a dormancy period during the coldest season of the year, wherein there is no visible growth of any plant structure involving a meristem. This response is fundamental to assuring tissue resistance to cold temperatures (FALAVIGNA et al., 2018). Dormancy release occurs naturally after a certain extent of cold stratification, termed accumulated cold units (ACU) is reached (HAWERROTH et al., 2010a).

In Brazil, the regions where apple trees are grown frequently show ACU below the need of the main cultivars, which causes uneven and decreased budburst, little formation of flower clusters, and decrease of yield and fruit quality (ATKINSON et al., 2013; HAWERROTH et al., 2009, 2010a; PASA et al., 2018; PETRI; LEITE, 2004). To compensate for the lack of cold and allow fruit production, various handling practices, such as chemical spraying, are applied in order to increase the budburst (RADY; El-YAZAL, 2013).

The main bud-breaking agent used in Brazil is a mixture of hydrogen cyanamide (HC) and mineral oil (MO) (HAWERROTH et al., 2010a). This combination has shown good efficiency and has been used for several years. However, restricted spraying of $\mathrm{HC}$ has been imposed, mainly in conditions of integrated fruit production (HAWERROTH et al., $2010 \mathrm{~b}$ ), with selling restrictions in some countries, as occurred for a limited time in Italy after an acute intoxication of sprayers was confirmed (PETRI et al., 2008; SETTIMI et al., 2005).

As a result, several alternative products were studied, including garlic extracts (BOTELHO; MÜLLER, 2007; OLIVEIRA et al., 2009), onion extracts (RADY; EL-YAZAL, 2013), thidiazuron (TDZ) (CAMPOY et al., 2010), Erger $^{\circledR}$ (HAWERROTH et al., 2010b; HOEBERICHTS et al., 2017), among others. Erger ${ }^{\circledR}$ is a biostimulator containing inorganic nitrogen and polysaccharides, with low toxicity. When applied with calcium nitrate, it induces budburst of apical and axillary buds on species, such as apple trees and kiwifruit vines (HOEBERICHTS et al., 2017; PETRI et al., 2008). The mode of action involves the increased expression of genes linked to glutamine and glutamate biosynthesis, as well as enhanced ammonia assimilation, nitrogen fixation, amino acids homeostasis, protein secretion, gibberellin biosynthesis, glycolysis intensification, oxidation/ reduction processes, and intracellular transports, for example (HOEBERICHTS et al., 2017).

Based on the foregoing, the current work aimed to evaluate the efficiency of different products on the induction of budburst of apical and axillary buds, and the effect on the return bloom, the yield, and the fruit mass of 'Eva' apple tree under the conditions of Eldorado do Suk, a region of low ACU, during three productive years.

\section{Material and Methods}

The experiment was conducted in the Estação Experimental Agronômica da Universidade Federal do Rio Grande do Sul, located in Eldorado do Sul/ RS, Brazil, on 2013/14, 2014/15, and 2015/16. The region has a Köppen climate classification of $C f a$, described as humid subtropical with warm summer (KUINCHTNER; BURIOL, 2001). An 'Eva' apple tree orchard aged around 6 years was used, grafted over Marubakaido using an M.9 interstem. The planting spacing was $5 \times 1.5 \mathrm{~m}$, with central leader training supported on spalier. 
The experiment was arranged in randomized blocks, with six repetitions of one useful plant. The treatments (dormancy-breaking chemicals) were as follows: 1) Control (no spraying); 2) 4\% $\mathrm{MO}$; 3) $4 \% \mathrm{MO}+0.6 \% \mathrm{HC}\left(1.2 \%\right.$ Dormex $\left.^{\circledR}\right)$; 4) $3 \%$ $\mathrm{Ca}\left(\mathrm{NO}_{3}\right)_{2}(15.5 \% \mathrm{~N}$ and $\left.19 \% \mathrm{Ca}) ; 5\right) 3 \% \mathrm{Ca}\left(\mathrm{NO}_{3}\right)_{2}$ $+2 \%$ Erger $\left.^{\circledR} ; 6\right) 3 \% \mathrm{Ca}\left(\mathrm{NO}_{3}\right)_{2}+3 \%$ Erger $\left.^{\circledR} ; 7\right)$ $3 \% \mathrm{Ca}\left(\mathrm{NO}_{3}\right)_{2}+4 \%$ Erger $\left.^{\circledR} ; 8\right) 3 \% \mathrm{Ca}\left(\mathrm{NO}_{3}\right)_{2}+5 \%$ Erger $^{\circledR}$. Spraying was performed using a manual backpack sprayer to the point of "run-off", always in the last week of July.

The following aspects were evaluated: budburst rate and physiological changes in buds, return bloom, yield, and fruit mass. For the budburst rate evaluation of the apical buds, 2 branches were marked per plant during the dormancy period. The total number of apical buds was counted in every structure of the branch (spurs and shoots). The budburst of axillary buds was determined by marking four shoots during the dormancy. The counting of apical and axillary buds was performed periodically, related to the total number of buds counted previously. The yield was determined by harvesting and weighing all fruits from the plant. For the return bloom determination, all flower clusters of each plant were counted when they were in the full-bloom stage ( $70 \%$ of flowers opened), on the crops of 2014/15 and 2015/16. Before harvest, the number of fruits per plant was determined, and the effective fructification was calculated, being expressed as fruits per flower cluster.

In the crop of $2015 / 16$, enzyme activity and peroxide content were assessed on the apical buds 5 days after spraying the treatments. The buds were immediately saved in liquid nitrogen. At the laboratory, the buds were ground using a mortar and pistil in liquid nitrogen. An aliquot of $350 \mathrm{mg}$ of the material was weighed, and then $4 \mathrm{~mL}$ of sodium acetate buffer (100 mM, pH 5.0) and $200 \mathrm{mg}$ PVPP were added, followed by centrifugation at 20,000 $g, 4^{\circ} \mathrm{C}$ for $30 \mathrm{~min}$. The peroxidase and catalase activities of the supernatant were measured. For assaying catalase activity, $50 \mu \mathrm{L}$ of enzyme extract +
$2.95 \mathrm{~mL}$ of a solution containing sodium phosphate buffer (0.01 M, pH 6.0), $0.05 \mathrm{~mL}$ guaiacol and $0.03 \mathrm{~mL}$ of $\mathrm{H}_{2} \mathrm{O}_{2}$ were combined. The change in absorbance was monitored in a spectrophotometer (T60U PG Instruments) at $470 \mathrm{~nm}$, and the activity results were calculated according to Velikova et al. (2000). To determine the peroxidase activity, $100 \mu \mathrm{L}$ of enzyme extract $+2.90 \mathrm{~mL}$ of a solution containing sodium phosphate buffer $(0.05 \mathrm{M}, \mathrm{pH}$ 7.0) and $0.03 \mathrm{~mL}$ of $\mathrm{H}_{2} \mathrm{O}_{2}$ were mixed. The change in absorbance was determined at $240 \mathrm{~nm}$, and the quantity was expressed as enzyme units $\mathrm{g}^{-1}$ of fresh weight (FW) (adapted from VELIKOVA et al., 2000).

For measurement of the $\mathrm{H}_{2} \mathrm{O}_{2}$ content, 100 $\mathrm{mg}$ of ground tissue was added to $5 \mathrm{~mL}$ of $0.1 \%$ trichloroacetic acid (TCA), followed by centrifugation at $12,000 \mathrm{~g}, 4^{\circ} \mathrm{C}$ for $15 \mathrm{~min}$. After, 0.5 $\mathrm{mL}$ of the supernatant was withdrawn and added to $0.5 \mathrm{~mL}$ of potassium phosphate buffer $(0.01, \mathrm{M} \mathrm{pH}$ 7.0) and $2 \mathrm{~mL}$ of $1 \mathrm{M}$ potassium iodide solution (KI). The reading was performed in a spectrophotometer at $390 \mathrm{~nm}$ and the concentration obtained was compared to the $\mathrm{H}_{2} \mathrm{O}_{2}$ standard curve $(0-100 \mu \mathrm{M})$ and expressed as $\mu \mathrm{mol} \mathrm{\textrm {g } ^ { - 1 }}$ of FW (adapted from RADY; EL-YAZAL, 2013).

Data were analyzed as repeated measures using the SAS $^{\circledR}$ PROC MIXED procedure, with the year as an intrinsic factor. Covariance structures were tested, and the one that presented the best adjustment to the data was selected, according to the Akaike information criteria (AIC) and the Bayesian information criteria (BIC). Interactions between factors were considered significant when $\mathrm{p} \leq 0.25$ (PERECIN; CARGNELUTTI FILHO, 2008). Orthogonal contrasts were built to compare the treatments: $\mathrm{C} 1$ (control $\times$ budburst-inducing chemicals) and $\mathrm{C} 2\left(\mathrm{MO}+\mathrm{HC} \times \mathrm{Ca}\left(\mathrm{NO}_{3}\right)_{2}+\right.$ Erger $^{\mathbb{R}}$ ). Regression models were adjusted for the determination of the rate of apical, axillary or the average of apical and axillary behavior, in response to Erger $^{\circledR}$ doses. The relationship between the variables was confirmed by Pearson's correlation. 


\section{Results and Discussion}

Budburst-inducing chemicals were efficient at increasing the budburst rate of apical and axillary buds in all evaluated years. On the apical buds, the budburst rate reached close to $100 \%$ (Figures
1, 2, and 3). For axillary buds, although there was some increase in the budburst rate in response to the treatments, it did not surpass $45.1 \%$, which was reached in 2015/16, representing the highest rate among the evaluated years (Figure 3 ).

Figure 1. Bud burst rate of 'Eva' apple tree in response to different bud burst inducers, in 2013/14, in Eldorado do Sul, RS.
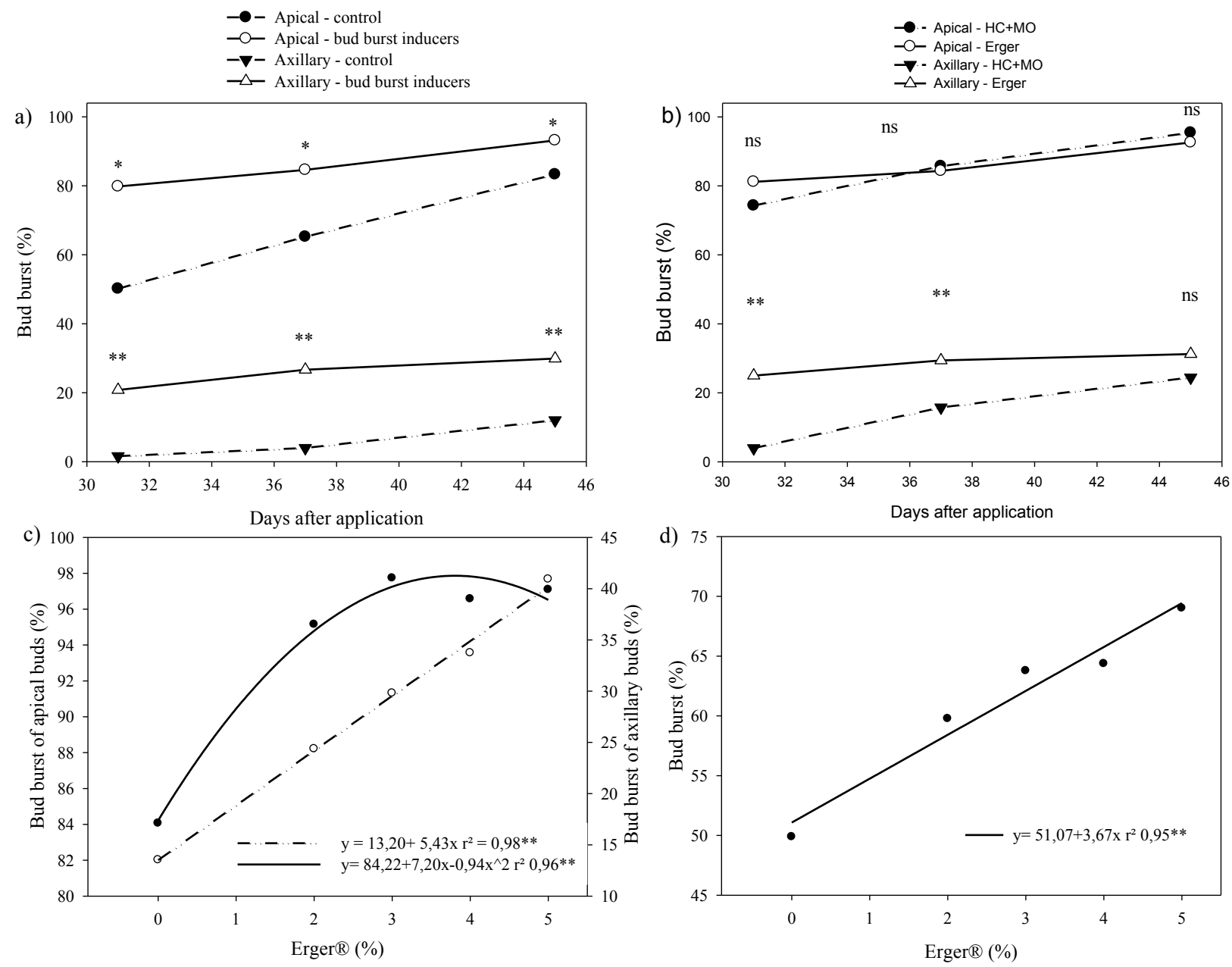

a) Bud burst of apical and axillary buds in the contrast control $\mathrm{x}$ bud burst inducers; $\mathrm{b}$ ) Bud burst of apical and axillary buds in the contrast MO 4\% + $\mathrm{HC} 0,6 \% \times \operatorname{Erger}^{\circledR}+\mathrm{Ca}\left(\mathrm{NO}_{3}\right)_{2}$; Bud burst behavior of apical or axillary buds (c) or in the average of apical and axillary (d) in response to Erger $^{\mathbb{B}}$ doses. ${ }^{*}$ significant at $5 \%$ of error probability; ${ }^{* *}$ significant at $1 \%$; ns- non significant.

MO spraying increased the final budburst rate of apical and axillary buds, but the unevenness of budburst was lower compared with Erger $^{\circledR}+$ $\mathrm{Ca}\left(\mathrm{NO}_{3}\right)_{2}$ or $\mathrm{HC}+\mathrm{MO}$ treatments (Figures 1, 2, and 3). Other authors also observed an increment in the budburst by the spraying of MO on 'Golden
Delicious' (SAGREDO, 2008), 'Imperial Gala' and 'Fuji Suprema' (HAWERROTH et al., 2009), and 'Royal Gala' (HAWERROTH et al., 2010a), although the efficiency was lower relative to that achieved with HC (MARCHI et al., 2017). 
Erger $^{\circledR}+\mathrm{Ca}\left(\mathrm{NO}_{3}\right)_{2}$ treatments efficiently increased the budburst rate of apical and axillary buds equivalent to the standard treatment with $0.6 \% \mathrm{HC}+3.5 \% \mathrm{MO}$ (Figures 1, 2, and 3). On the 2013/14 and 2015/16 crops, Erger ${ }^{\circledR}+\mathrm{Ca}\left(\mathrm{NO}_{3}\right)_{2}$ treatments accelerated the budburst of axillary buds, causing higher synchrony in comparison to plants exposed to $0.6 \% \mathrm{HC}+3.5 \% \mathrm{MO}$ treatment, which is a usual treatment in commercial apple orchards, due to its efficiency (HAWERROTH et al., 2009, 2010a; ROBERTO et al., 2006).

Figure 2. Bud burst rate of 'Eva' apple tree in response to different bud burst inducers, in 2014/15, in Eldorado do Sul, RS.
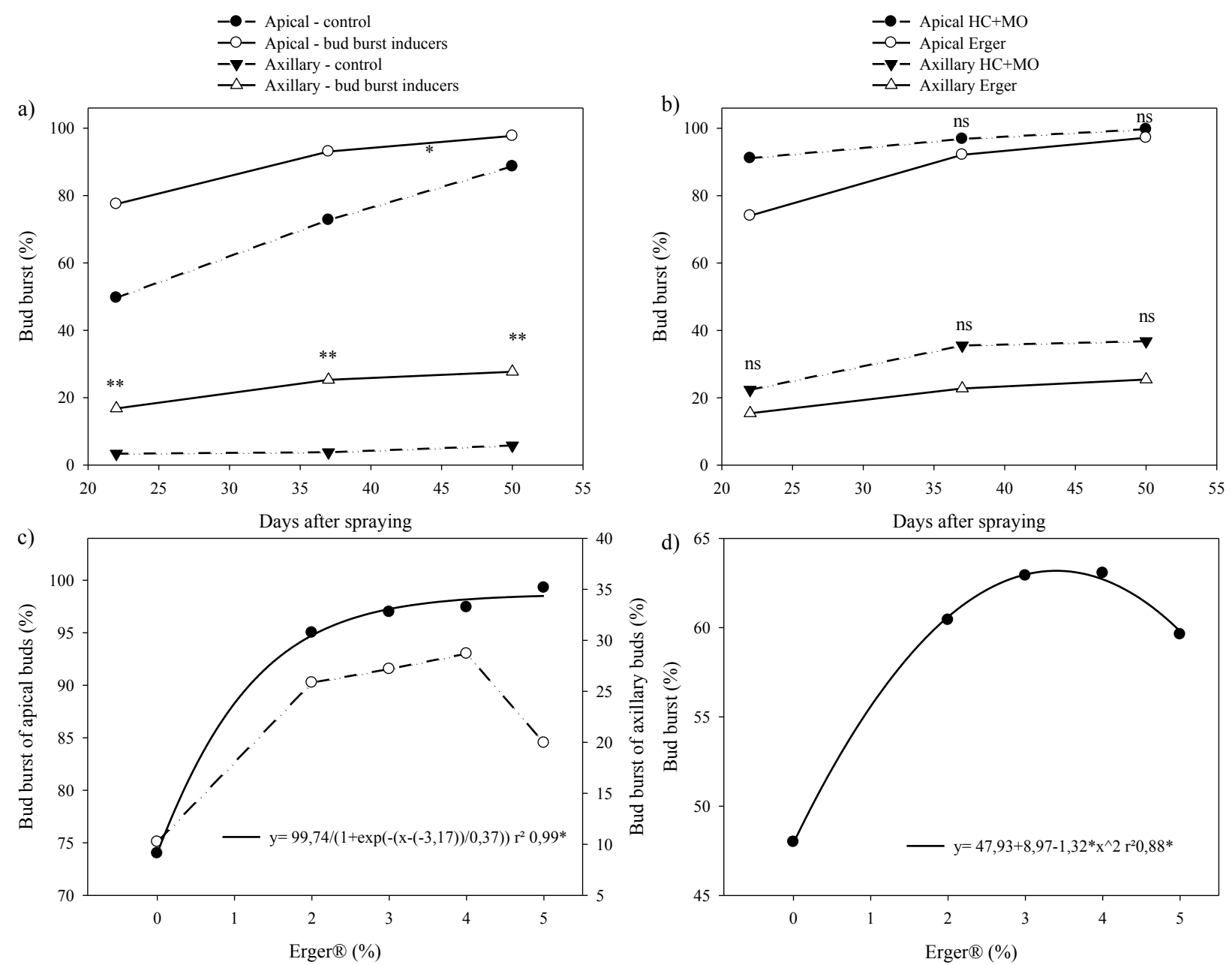

a) Bud burst of apical and axillary buds in the contrast control $x$ bud burst inducers; b) Bud burst of apical and axillary buds in the contrast MO 4\% + $\mathrm{HC} 0,6 \%$ Erger $^{\circledR}+\mathrm{Ca}\left(\mathrm{NO}_{3}\right)_{2}$; Bud burst behavior of apical or axillary buds (c) or in the average of apical and axillary (d) in response to Erger $^{\circledR}$ doses. * significant at $5 \%$ of error probability; ** significant at $1 \%$; ns- non significant.

Budburst-inducing products that cause a similar result to that of HC may be considered as promising, especially when they present low toxicity since this aspect may restrict $\mathrm{HC}$ use in the future (PETRI et al., 2014). The efficiency of Erger ${ }^{\circledR}$ in inducing increased budburst has already been observed in
'Imperial Gala' (HAWERROTH et al., 2010b), 'Fuji Suprema' (HAWERROTH et al., 2010b; PASA et al., 2018; UBER et al., 2017), 'Maxi Gala' (UBER et al., 2017), and 'Eva' and 'Castel Gala' apple trees (ABREU et al., 2018). 
Budburst behavior in response to Erger $^{\circledR}$ doses changed between the evaluated years, and different regression models were adjusted. In 2013/14, there was an increase in the budburst rate of apical and axillary buds up to a dose of $5 \%$ Erger $^{\circledR}$ (Figure 1c, d). In 2014/15 and 2015/16, the maximum budburst rate (the average of apical and axillary buds) was induced by the calculated dose of $3.4 \%$ Erger $^{\circledR}$
(Figures $2 \mathrm{~d}$ and $3 \mathrm{~d}$, respectively). In the three crops, the increase in the budburst rate of the axillary buds up to the highest doses was greater than that seen in the apical buds (Figures 1c, 2c, 3c). However, high doses, such as 4 and $5 \%$ Erger $^{\circledR}$, caused phytotoxicity, mainly on branches which had late growth, possibly because of inadequate lignification.

Figure 3. Bud burst rate of 'Eva' apple tree in response to different bud burst inducers, in 2014/15, in Eldorado do Sul, RS.
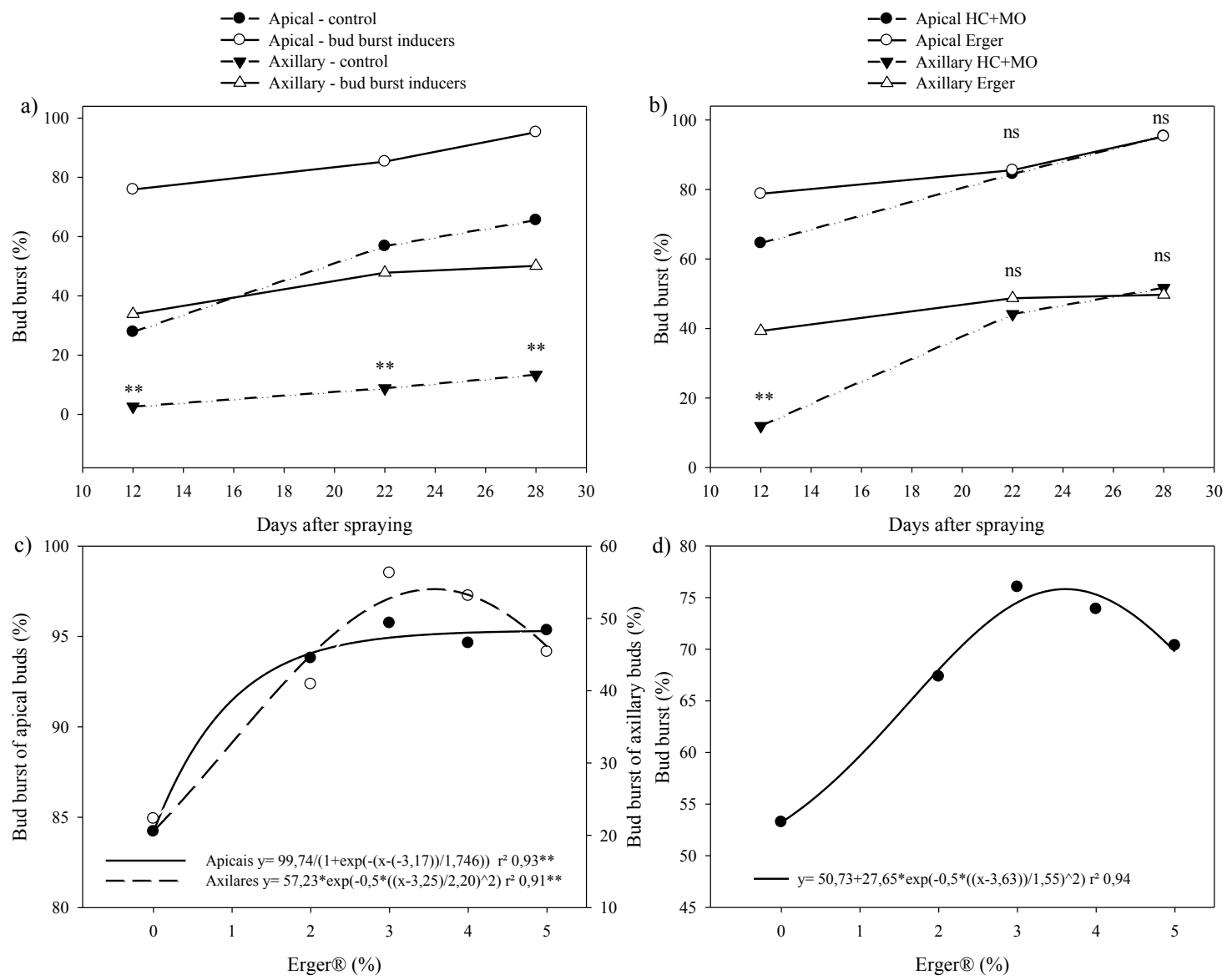

a) Bud burst of apical and axillary buds in the contrast control $\mathrm{x}$ bud burst inducers; b) Bud burst of apical and axillary buds in the

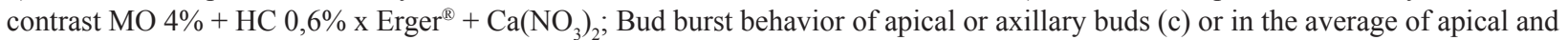
axillary (d) in response to Erger $^{\circledR}$ doses. ${ }^{*}$ significant at $5 \%$ of error probability; ${ }^{* *}$ significant at $1 \%$; ns- non significant.

Hawerroth et al. (2010b) noted an increase in budburst in response to increasing the Erger $^{\circledR}$ dose, although the average budburst ('Imperial Gala' and 'Fuji Suprema') of the 3\% dose did not differ from the higher doses. Likewise, the same trend was described by Uber et al. (2017) on 'Maxi
Gala' and 'Fuji Suprema' trees but, in that study, the budburst rate of $2 \%$ Erger $^{\circledR}$ did not differ from the higher doses. Pasa et al. (2018) reported the budburst of axillary buds, in plants exposed to 2,4 and $6 \%$ Erger $^{\circledR}$, was below the $0.34 \% \mathrm{HC}+3.2 \%$ MO standard treatment on 'Fuji Suprema' apple tree 
while the budburst of apical buds was high, even without the spraying of inducing chemicals (control treatment). According to Abreu et al. (2018), 3\% Erger $^{\circledR}$ was superior to $1.5 \% \mathrm{HC}+3 \% \mathrm{MO}$ at triggering increased budburst on 'Eva', whereas, both treatments had similar outcomes when applied to 'Castel Gala'.

The budburst-inducing chemical spray promoted higher return bloom compared with the control treatment (Figure 4). Although the MO treatment increased the average values of return bloom, it was lower relative to $\mathrm{HC}+\mathrm{MO}$ or $\mathrm{Ca}\left(\mathrm{NO}_{3}\right)_{2}+$ Erger $^{\mathbb{B}}$ treatments. Plants sprayed with $\mathrm{Ca}\left(\mathrm{NO}_{3}\right)_{2}+$ Erger $^{\circledR}$ or $\mathrm{HC}+\mathrm{MO}$ treatments showed similar flowering intensities to each other. Sagredo (2008) also found the spraying of $0.49 \% \mathrm{HC}+5 \% \mathrm{MO}$ increased the number of flower clusters on the third evaluated crop compared with the control treatment. In the present experiment, the increase in the number of flower clusters was related to the increased budburst, mainly of axillary buds, as reflected in the correlations (Figure 4b, c).

Figure 4. Return bloom in response to bud burst inducers spraying in 'Eva' apple tree in 2014/15 and 2015/16 in Eldorado do Sul, RS.
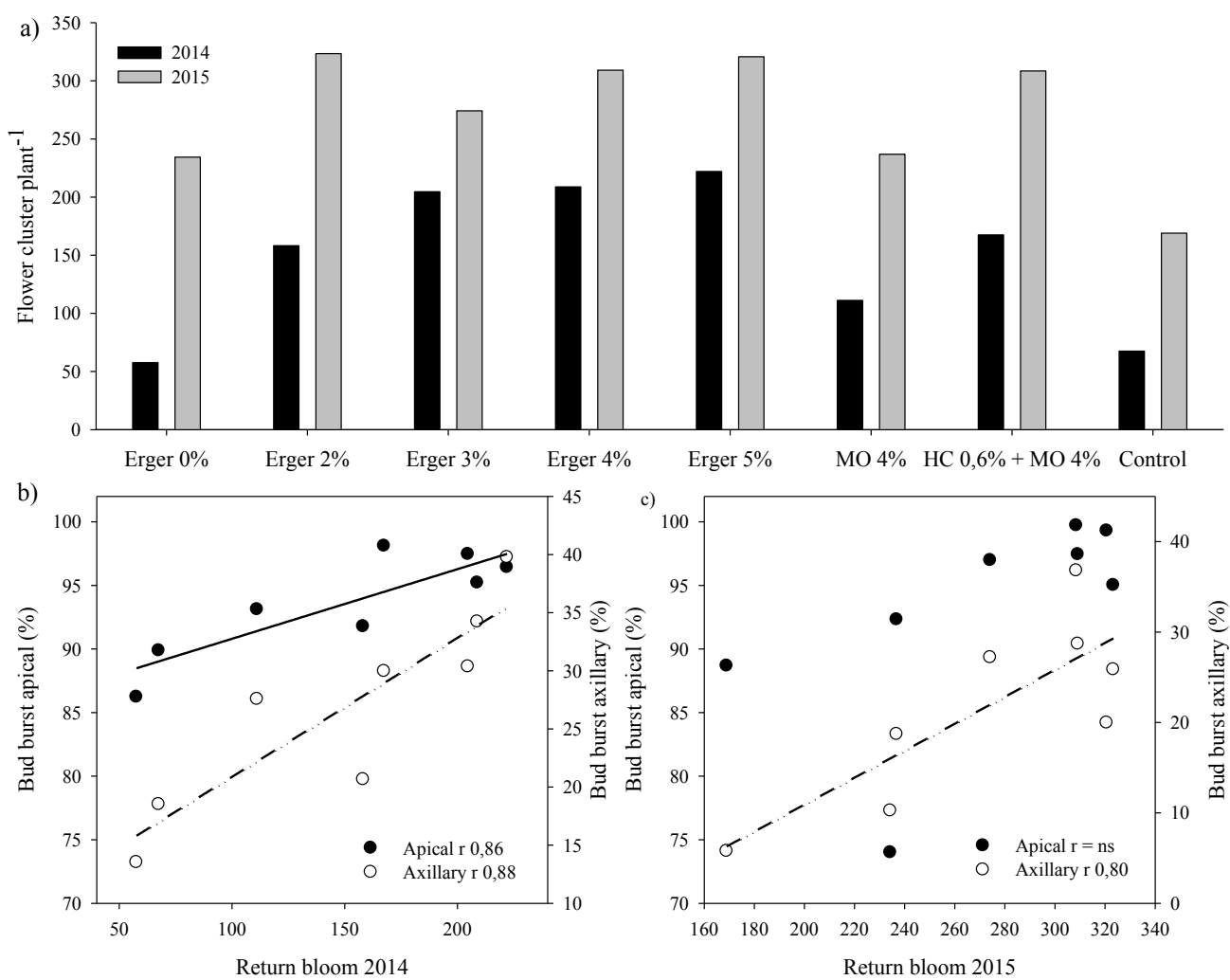

a) Number of flower clusters in 2014/15 and 2015/16; b) Correlation between the bud burst rate of apical and axillary in 2013/14 and the return bloom (flower clusters per plant) in 2014/15; c) Correlation between bud burst of apical and axillary buds in 2014/15 and the return bloom (flower clusters per plant) in 2015/16. ns- non significant.

The yield was affected by the budburst inducers in two of the three evaluated years (Table 1). In $2014 / 15$, the spraying of budburst inducers triggered an increase in the production relative to the control treatment, whereas, in the $2015 / 16$ crop, there was less production on plants that had been sprayed with different budburst inducers. Regarding the products, no difference was observed between the $0.6 \% \mathrm{HC}+$ $4 \mathrm{MO} \%$ and the Erger ${ }^{\circledR}+\mathrm{Ca}\left(\mathrm{NO}_{3}\right)_{2}$ treatments.

The change in apple tree productivity by the spraying of inducers was consistent with other authors. 
For instance, the spraying of $125 \mathrm{mg} \mathrm{L}^{-1} \mathrm{TDZ}+3.5 \%$ $\mathrm{MO}$ or $250 \mathrm{mg} \mathrm{L}^{-1} \mathrm{TDZ}+5 \% \mathrm{Ca}\left(\mathrm{NO}_{3}\right)_{2}$ on 'Daiane' apple trees decreased the yield in one crop (DE MARTIN et al., 2017). In other work, the spraying of 'Fuji Suprema' with 3\% Erger ${ }^{\circledR}+3 \% \mathrm{Ca}\left(\mathrm{NO}_{3}\right)_{2}, 5 \%$ Erger $^{\circledR}+5 \% \mathrm{Ca}\left(\mathrm{NO}_{3}\right)_{2}$ or $7 \%$ Erger $^{\circledR}+7 \% \mathrm{Ca}\left(\mathrm{NO}_{3}\right)_{2}$ increased productivity in one of the two evaluated crops while none of the treatments promoted an increment in the productivity of 'Royal Gala', and 7\% Erger $^{\circledR}+7 \% \mathrm{Ca}\left(\mathrm{NO}_{3}\right)_{2}$ even reduced the productivity relative to the control (HAWERROTH et al., 2010b).
The same authors found that the spraying of 'Royal Gala' with $0.29 \% \mathrm{HC}+3.2 \% \mathrm{MO}$ increased the yield in one crop while $0.39 \% \mathrm{HC}$ had the same effect as the control treatment in one crop and was lower than the control in another (HAWERROTH et al., 2010a). Other researchers mentioned that the spraying of 'Eva' with 3\% Erger $^{\circledR}+3 \% \mathrm{Ca}\left(\mathrm{NO}_{3}\right)_{2}$ or $5 \%$ Erger $^{\circledR}$ $+5 \% \mathrm{Ca}\left(\mathrm{NO}_{3}\right)_{2}$ increased productivity relative to the control treatment in one evaluated crop, but on 'Castel Gala', no difference was detected (ABREU et al., 2018).

Table 1. Yield ( $\mathrm{kg} \mathrm{plant}^{-1}$ ) and average fruit mass (AFM) of 'Eva' apple tree in response to bud burst inducers spraying in 2013/14, 2014/15 e 2015/16, in Eldorado do Sul, RS.

\begin{tabular}{|c|c|c|c|c|c|c|c|}
\hline \multirow[b]{2}{*}{ Treatment } & \multicolumn{4}{|c|}{$\mathrm{kg}_{\text {plant }}{ }^{-1}$} & \multicolumn{3}{|c|}{$\operatorname{AFM}(\mathrm{g})$} \\
\hline & $2013 / 14$ & $2014 / 15$ & $2015 / 16$ & cumulate & $2013 / 14$ & $2014 / 15$ & $2015 / 16$ \\
\hline $\mathrm{Ca}\left(\mathrm{NO}_{3}\right)_{2}$ & 12.00 & 7.88 & 11.53 & 27.92 & 109.18 & 88.59 & 60.60 \\
\hline $\mathrm{Ca}\left(\mathrm{NO}_{3}\right)_{2}+$ Erger $2 \%$ & 10.51 & 12.66 & 6.96 & 32.52 & 97.60 & 103.89 & 69.35 \\
\hline $\mathrm{Ca}\left(\mathrm{NO}_{3}\right)_{2}+$ Erger $3 \%$ & 9.87 & 12.87 & 3.36 & 28.09 & 108.79 & 118.47 & 78.38 \\
\hline $\mathrm{Ca}\left(\mathrm{NO}_{3}\right)_{2}+$ Erger $4 \%$ & 11.19 & 11.91 & 4.28 & 31.41 & 115.32 & 121.98 & 75.60 \\
\hline $\mathrm{Ca}\left(\mathrm{NO}_{3}\right)_{2}+$ Erger $5 \%$ & 9.84 & 11.07 & 2.94 & 30.91 & 119.48 & 121.09 & 72.92 \\
\hline MO 4\% & 12.13 & 11.76 & 8.63 & 26.09 & 117.02 & 100.09 & 67.12 \\
\hline $\mathrm{MO} 4 \%+\mathrm{HC} 0.6 \%$ & 12.51 & 12.3 & 3.03 & 27.37 & 115.54 & 120.62 & 74.76 \\
\hline \multirow[t]{3}{*}{ Control } & 11.46 & 8.51 & 7.97 & 23.84 & 113.62 & 100.28 & 64.98 \\
\hline & \multicolumn{7}{|c|}{ ANOVA } \\
\hline & Test $\mathrm{F}$ & & $\operatorname{Pr}>F$ & $\operatorname{Pr}>F$ & Teste F & & $\operatorname{Pr}>F$ \\
\hline Treatment & 0.92 & & 0.5002 & 0.4996 & 4.27 & & $0.0018^{* *}$ \\
\hline Year & 70.75 & & $<.0001 * *$ & (cumulate) & 129.29 & & $<.0001 * *$ \\
\hline \multirow[t]{2}{*}{ Treatment*Year } & 4.01 & & $<.0003 * *$ & & 1.77 & & 0.0755 \\
\hline & \multicolumn{7}{|c|}{ Contrasts $(\operatorname{Pr}>\mathrm{F})$} \\
\hline $\mathrm{C} 1$ & 0.53 & $0.006^{* *}$ & $0.0001 * *$ & & & $0.0009 *$ & \\
\hline $\mathrm{C} 2$ & 0.17 & 0.93 & 0.33 & & & 0.3969 & \\
\hline
\end{tabular}

MO: mineral oil; $\mathrm{HC}$ : hydrogen cyanamide; $\mathrm{Ca}\left(\mathrm{NO}_{3}\right)_{2} ; *$ Significantata $\mathrm{p}<0.05 ; * *$ Significant at $\mathrm{p}<0.01$.

The budburst inducers induced larger fruits than the control treatment (Table 1), corroborating the trend seen in several literature studies that show an increase in fruit mass in response to bud burst inducers (ABREU et al., 2018; HAWERROTH et al., 2010b,c; DE MARTIN et al., 2017). There was no difference between the $\operatorname{Erger}^{\circledR}+\mathrm{Ca}\left(\mathrm{NO}_{3}\right)_{2}$ and
$\mathrm{HC}+\mathrm{MO}$ treatments. Regarding the Erger ${ }^{\circledR}$ doses, the fruit mass increased linearly in response to the increase in dose $\left(y=85.67+4.19 x, \mathrm{r}^{2}=0.94\right)$.

The negative impact of the budburst inducers on the $2015 / 16$ yield is possibly related to the higher synchrony with the budburst period between the plant buds, thereby concentrating the flowering 
in a short period, reducing the effective period of pollination. Another aspect is that the budburst inducers caused a high number of flower clusters in this year, which increased the competition between the drain tissues and might have led to a carbohydrate deficiency due to the energetic demands from the different drains. Consequently, a reduction of the effective fructification may happen, as observed by Hawerroth et al. (2010a,b), and Abreu et al. (2018).

In the present experiment, in the 2014/15 and $2015 / 16$ crops, the increases in the bud burst rate (apical and axillary) and the number of flower clusters per plant were linked to the reduction of the effective fructification (Figure 5). In 2014/15, the increase in the number of flower clusters, although it was associated with the effective fructification drop, was an important factor for the yield increment, showing a positive correlation (Figure 5c). However, in 2015/16, plants sprayed with budburst inducers were less productive than the control treatment, and although there was no significant correlation, plants with a higher number of flower clusters showed a lower yield. Thus, the productive yield could be incremented by practices that favor the highest carbohydrate accumulation during the cycle, such as the permanence of the leaves for the maximum time possible, increasing the effective fructification rate (ALMEIDA; FIORAVANÇO, 2018). Another fundamental aspect is to assure the flower availability of other cultivars which show good flowering synchrony, besides ensuring a high density of pollinating insects (ABREU et al., 2018; HAWERROTH et al., 2010a,c).

Figure 5. Pearson Correlation between bud burst, flower clusters, effective fructification and yield per plant in 'Eva' apple tree undergone to bud burst inducers spraying, in 2014/15, 2015/16 in Eldorado do Sul, RS.
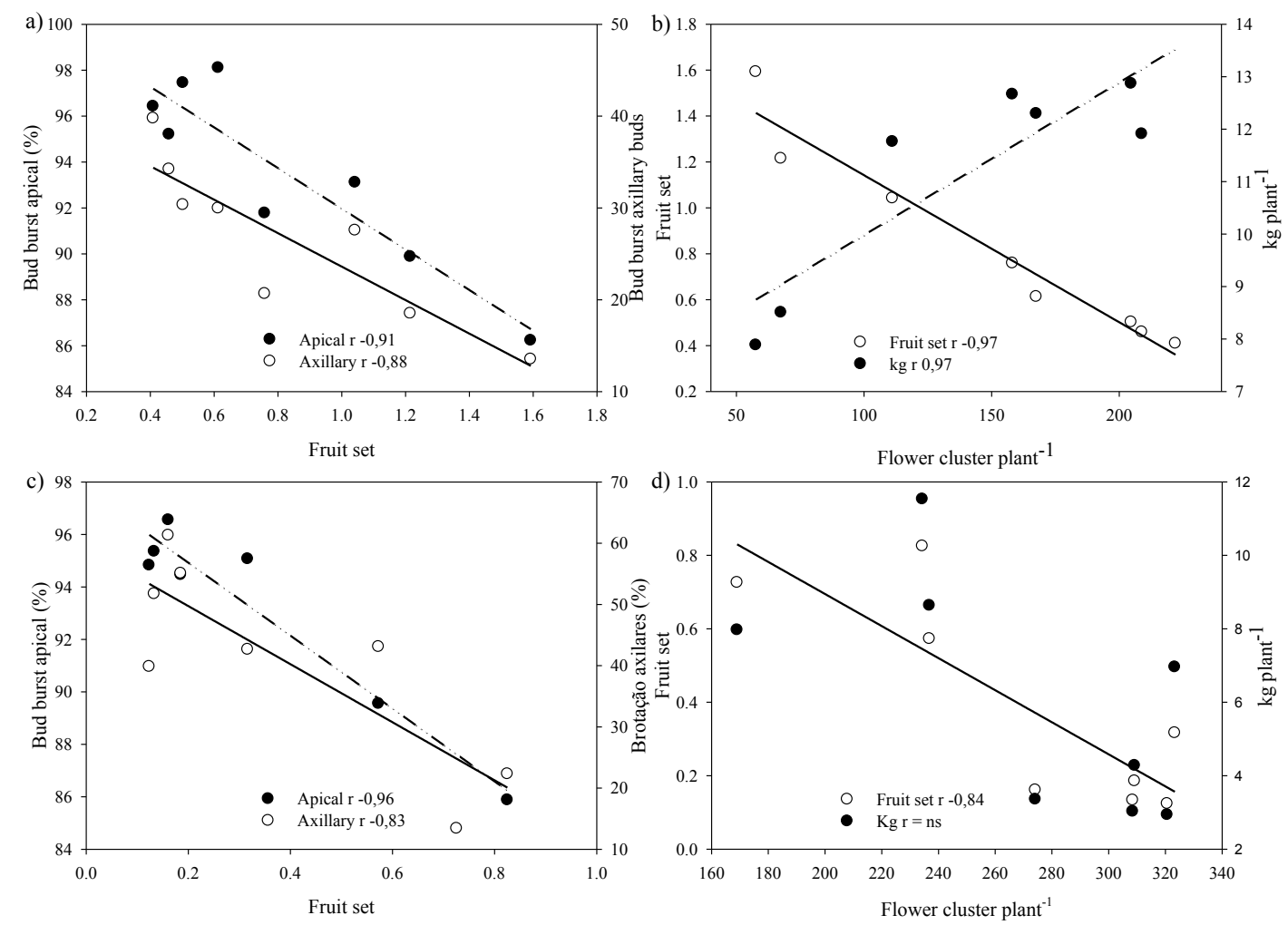

Correlation between bud burst rate of apical and axillary buds and the effective fructification rate, 2014/15 (a) and 2015/16 (c). Correlation between the effective fructification rate and the number of flower clusters per plant, 2014/15 (b) and 2015/16 (d). nsnon significant. 
Budburst inducers significantly affected the peroxidase enzyme activity at 5 days after spraying. The highest enzyme activity corresponded to the MO treatment (Figure 6). Catalase was not affected by the treatments. Conversely, the $\mathrm{H}_{2} \mathrm{O}_{2}$ content in the buds showed differences between treatments 5 days after spraying, as buds sprayed with Erger $^{\circledR}$ $+\mathrm{Ca}\left(\mathrm{NO}_{3}\right)_{2}$ had the lowest levels. The $\mathrm{HC}+\mathrm{MO}-$ treated samples had lower $\mathrm{H}_{2} \mathrm{O}_{2}$ levels lower than the control.

Figure 6. Activity of catalase (CAT) and peroxidase (POD) enzymes, and the content of hydrogen peroxide $\left(\mathrm{H}_{2} \mathrm{O}_{2}\right)$ in apical buds of 'Eva' apple tree in response to bud burst inducers in 2016/17.
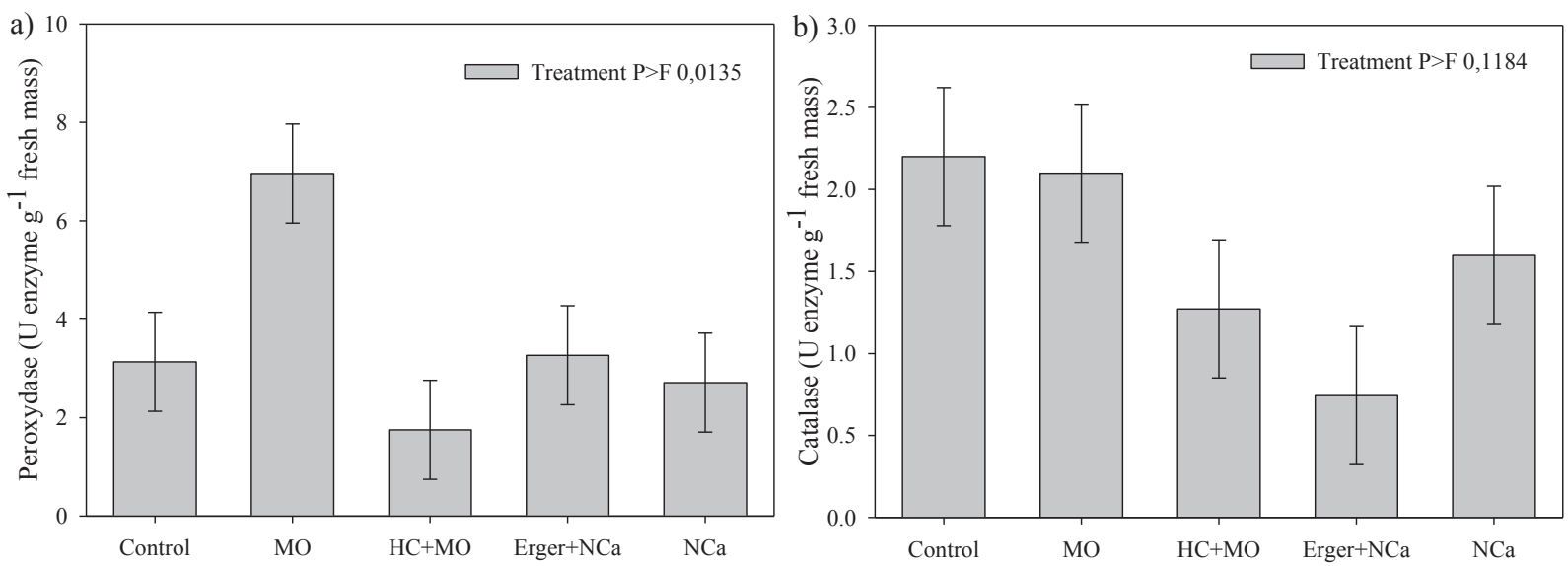

c)

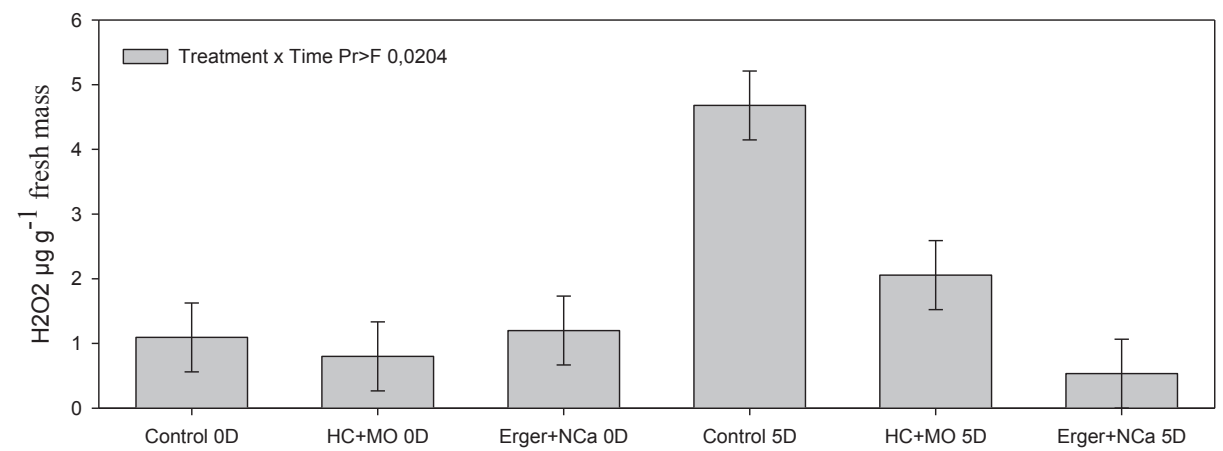

Activity of the enzymes peroxidase (a) and catalase (b), and hydrogen peroxide $\left(\mathrm{H}_{2} \mathrm{O}_{2}\right)$ content (c) in apical buds of 'Eva' apple tree. Bars indicate the median absolute deviation.

Atividade da enzima peroxidase (a), catalase (b) e teores de peróxido de hidrogênio $\left(\mathrm{H}_{2} \mathrm{O}_{2}\right)$ em gemas apicais de macieira 'Eva'. Barras indicam o desvio padrão da média.

One of the expected outcomes due to $\mathrm{HC}$ spraying is the decrease in catalase activity, which, in turn, increases $\mathrm{H}_{2} \mathrm{O}_{2}$ concentration (NIR et al., 1986). However, the present experiment did not reveal any significant reduction relative to the control treatment. It is possible that this effect may be occurring on the days closer to the spraying and the bud collection period has happened late, so the effect was not recorded. Marchi et al. (2017) noticed a decline in the levels of catalase $24 \mathrm{~h}$ after spraying of $\mathrm{HC}+\mathrm{MO}$ treatment; however, the spraying of MO and vegetable oils (soybean and sunflower), individually, did not cause the same effect. For the peroxidase enzyme, the authors did not observe any influence of the treatments $24 \mathrm{~h}$ after spraying.

In the sampling made before spraying the inducers, the $\mathrm{H}_{2} \mathrm{O}_{2}$ levels were similar between the treatments $\left(1.03 \mu \mathrm{mol} \mathrm{g}^{-1} \mathrm{FM}\right.$ on average; Figure 6). 
At 5 days after spraying, the $\mathrm{H}_{2} \mathrm{O}_{2}$ concentration was higher in the control treatment $\left(4.68 \mu \mathrm{mol} \mathrm{g} \mathrm{g}^{-1} \mathrm{FM}\right)$ and $\mathrm{MO}+$ Dormex $^{\circledR}$ treatment $\left(2.06 \mu \mathrm{mol} \mathrm{g}{ }^{-1} \mathrm{FM}\right)$, when compared with the levels before spraying. Exposure to $\mathrm{Ca}\left(\mathrm{NO}_{3}\right)_{2}+$ Erger $^{\circledR}$ resulted in a slight decrease in the $\mathrm{H}_{2} \mathrm{O}_{2}$ levels after spraying, but the difference was not significant.

$\mathrm{H}_{2} \mathrm{O}_{2}$ acts as a signaling molecule of several biological processes in the plant tissues, such as growth, development, and response to stressful conditions (BAXTER et al., 2013). Its levels increases under stress conditions, such as, during the buds dormancy period, as the ACU increases, but also in response to the spraying of budburst inducers, such as HC or onion extract (BAXTER et al., 2013; KURODA et al., 2002; RADY; ELYAZAL, 2013; SUDAWAN et al., 2016). The variations in the levels of $\mathrm{H}_{2} \mathrm{O}_{2}$ occur right after the spraying of the inducers. In pear tree buds, immediately after spraying with $\mathrm{HC}$, there was a reduction in the $\mathrm{H}_{2} \mathrm{O}_{2}$ levels, showing values lower than the control (KURODA et al., 2002), which agrees with that seen in the present experiment. However, 6 days after spraying of $\mathrm{HC}$, the $\mathrm{H}_{2} \mathrm{O}_{2}$ levels increased in pear tree buds (KURODA et al., 2002), which was also observed in apple tree buds 8 days after spraying of onion extract, keeping the values higher than those of the control until the budding period (RADY; EL-YAZAL, 2013). Erger ${ }^{\circledR}$ also influences the content of $\mathrm{H}_{2} \mathrm{O}_{2}$ in the meristems, as demonstrated when comparing the response to the spraying of other inducers, affecting the physiological processes which stimulate budburst.

\section{Conclusion}

Spraying of $\operatorname{Erger}^{\circledR}+\mathrm{Ca}\left(\mathrm{NO}_{3}\right)_{2}$ promotes an increase in the budburst rate of apical and axillary buds, of the return bloom, and the fruit average fresh mass of 'Eva' apple tree. Doses close to 3.4\% Erger $^{\circledR}$ encourage higher budburst values than lower doses and doses over $4 \%$ cause phytotoxicity.
The spraying of budburst inducers causes an increase in the peroxidase activity and decreases the $\mathrm{H}_{2} \mathrm{O}_{2}$ content 5 days after spraying, presenting an effect similar to the response to Erger $^{\circledR}$ or $\mathrm{HC}$ spraying.

\section{References}

ABREU, E. S.; CARRA, B.; SPAGNOL, D.; SCHMITZ, J. D.; SILVA, T. A.; HELLWIG, C. G.; FACHINELLO, J. C. Evaluation of the effect of different budbreak promoters on apple trees Eva and Castel Gala in mild winter climate conditions. Journal of Experimental Agriculture International, Londres, v. 20, n. 1, p. 1-7, 2018.

ALMEIDA, G. K.; FIORAVANÇO, J. C. Yield of Royal Gala apple trees in response to pruning before or after leaf drop. Pesquisa Agropecuária Brasileira, Brasília, v. 53, n. 4, p. 427-434, 2018. DOI: 10.1590/s0100$204 \times 2018000400004$

ATKINSON, C. J.; BRENNAN, R. M.; JONES, H. G. Declining chilling and its impact on temperate perennial crops. Environmental and Experimental Botany, Oxford, v. 91, n. 1, p. 48-62, 2013. DOI: 10.1016/j. envexpbot.2013.02.004

BAXTER, A.; MITTLER, R.; SUZUKI, N. ROS as key players in plant stress signalling. Journal of Experimental Botany, Lancaster, v. 65, n. 5, p. 1229-1240, 2013. DOI: $10.1093 / \mathrm{jxb} / \mathrm{ert} 375$

BOTELHO, R.; MÜLleR, M. Extrato de alho como alternativa na quebra de dormência de gemas em macieiras cv. Fuji Kiku. Revista Brasileira de Fruticultura, Jaboticabal, v. 29, n. 1, p. 37-41, 2007.

CAMPOY, J. A.; RUIZ, D.; EGEA, J. Effects of shading and thidiazuron+oil treatment on dormancy breaking, blooming and fruit set in apricot in a warm-winter climate. Scientia Horticulturae, Amsterdam, v. 125, n. 3, p. 203-210, 2010. DOI: 10.1016/j.scienta.2010.03.029

DE MARTIN, M. S.; PETRI, J. L.; FENILI, C. L.; GABARDO, G. C. Quebra da dormência de macieiras 'Daiane' pelo uso do tidiazurom. Revista de Ciências Agroveterinárias, Lages, v. 16, n. 2, p. 81-87, 2017. DOI: $10.5965 / 223811711622017081$

FALAVIGNA, V. S.; PORTO, D. D.; MIOTTO, Y. E.; SANTOS, H. P.; OLIVEIRA, P. R. D.; MARGISPINHEIRO, M.; PASQUALI, G.; REVERS, L. F. Evolutionary diversification of galactinol synthases in Rosaceae: adaptive roles of galactinol and raffinose 
during apple bud dormancy. Journal of Experimental Botany, Oxford, v. 69, n. 5, p. 1247-1259, 2018. DOI: 10.1093/jxb/erx451

HAWERROTH, F. J.; PETRI, J. L.; HERTER, F. G.; LEITE, G. B.; LEONETTI, J. F.; MARAFON, A. C.; SIMÕES, F. Fenologia, brotação de gemas e produção de frutos de macieira em resposta à aplicação de cianamida hidrogenada e óleo mineral. Bragantia, Campinas, v. 68, n. 4, p. 961-971, 2009.

HAWERROTH, F. J.; PETRI, J. L.; LEITE, G. B. Budbreak induction in apple trees by erger and calcium nitrate application. Acta Horticulturae, The Hague, v. 884 , n. 1, p. 511-516, 2010c. DOI: 10.17660/ ActaHortic.2010.884.65

HAWERROTH, F. J.; PETRI, J. L.; LEITE, G. B. Cianamida hidrogenada, óleos mineral e vegetal na brotação de gemas e produção de macieiras Royal Gala. Semina: Ciências Agrárias, Londrina, v. 31, p. 11451154, 2010a. Suplemento 1.

HAWERROTH, F. J.; PETRI, J. L.; LEITE, G. B.; HERTER, F. G. Brotação de gemas em macieiras Imperial Gala e Fuji Suprema pelo uso de Erger ${ }^{\circledR}$ e nitrato de cálcio. Revista Brasileira de Fruticultura, Jaboticabal, v. 32, n. 2, p. 343-350, 2010 b.

HOEBERICHTS, F. A.; POVERO, G.; IBAÑEZ, M.; STRIJKER, A.; PEZZOLATO, D.; MILLS, R.; PIAGGESI, A. Next generation sequencing to characterize the breaking of bud dormancy using a natural biostimulant in kiwifruit (Actinidia deliciosa). Scientia Horticulturae, Amsterdam, v. 225, n. 1, p. 252263, 2017. DOI: 10.1016/j.scienta.2017.07.011

KUINCHTNER, A.; BURIOL, G. A. Clima do Estado do Rio Grande do Sul segundo a classificação climática de Köppen e Thornthwaite. Disciplinarum Scientia: Ciências Naturais e Tecnológicas, Santa Maria, v. 2, n. 1, p. 171-182, 2001.

KURODA, H.; SUGIURA, T.; ITO, D. Changes in hydrogen peroxide content in flower buds of Japanese pear (Pyrus pyrifolia Nakai) in relation to breaking of endodormancy. Journal of the Japanese Society for Horticultural Science, Kyoto, v. 71, n. 5, p. 610-616, 2002.

MARCHI, T.; OLIARI, I. C. R.; MAIA, A. J.; SATO, A. J.; BOTELHO, R. V. Indução da brotação de gemas de macieiras com aplicação de óleos vegetais e mineral. Ciência Agronômica, Fortaleza, v. 48, n. 3, p. 501-512, 2017. DOI: 10.5935/1806-6690.20170059

NIR, G.; SHULMAN, Y.; FANBERSTEIN, L.; LAVEE, $\mathrm{S}$. Changes in the activity of catalase (EC 1.11.1.6) in relation to the dormancy of grapevine (Vitis vinifera L.)
Buds. Plant Physiology, Bethesda, v. 81, n. 4, p. 11401142, 1986. DOI: 10.1104/pp.81.4.1140

OLIVEIRA, O.; LIPSKI, B.; SILVA, E. D. B.; BIASI, L. A.; COELHO, S. S. Extrato de alho na superação da dormência de pereira Housui. Scientia Agraria, Curitiba, v. 10, n. 4, p. 283-288, 2009. DOI: 10.5380/rsa. v10i4.14772

PASA, M. D. S.; FELIPPETO, J.; NAVA, G.; SILVA, C. P. D.; BRIGHENTI, A. F.; CIOTTA, M. N. Performance of Fuji Suprema apple trees treated with budbreak promoters, in São Joaquim-SC. Revista Brasileira de Fruticultura, Jaboticabal, v. 40, n. 1, p. e-325, 2018.

PERECIN, D.; CARGNELUTTI FILHO, A. Efeitos por comparações e por experimento em interações de experimentos fatoriais. Ciência e Agrotecnologia, Lavras, v. 32, n. 1, p. 68-72, 2008.

PETRI, J. L.; LEITE, G. B. Consequences of insufficient winter chilling on apple tree bud-break. Acta Horticulturae, The Hague, v. 662, n. 1, p. 53-60, 2004. DOI: 10.17660/ActaHortic.2004.662.4

PETRI, J. L.; LEITE, G. B.; GABARDO, G. C.; HAWERROTH, F. J. Chemical induction of budbreak: new generation products to replace hydrogen cyanamide. Acta Horticulturae, The Hague, v. 1042, n. 1, p. 159-166, 2014. DOI: 10.17660/ActaHortic.2014.1042.19

PETRI, J. L.; LEITE, G. B.; PUTTI, G. L. Apple tree budbreak promoters in mild winter conditions. Acta Horticulturae, The Hague, v. 771, n. 1, p. 291-296, 2008. DOI: 10.17660/ActaHortic.2008.774.39

RADY, M.; EL-YAZAL, M. Response of Anna apple dormant buds and carbohydrate metabolism during floral bud break to onion extract. Scientia Horticulturae, Amsterdam, v. 155, n. 9, p. 78-84, 2013. DOI: 10.1016/j. scienta.2013.02.025

ROBERTO, S.; KAGUEYAMA, M.; SANTOS, C. Indução da brotação da macieira Eva em região de baixa incidência de frio. Revista Brasileira de Fruticultura, Jaboticabal, v. 28, n. 1, p. 128-130, 2006.

SAGREDO, K. X. Effect of rest-breaking and fruit thinning treatments on reproductive development in apple. Stellenbosch, South Africa. 2008. Thesis (PhD in Horticulture) - Stellenbosch University, Stellenbosch.

SETTIMI, L.; DAVANZO, F.; FARAONI, L.; MICELI, G.; RICHMOND, D.; CALVERT, G. M. Update: Hydrogen Cyanamide-related Ilnesses-Italy, 2002-2004. Morbidity and Mortality Weekly Report, Atlanta, v. 54, n. 16, p. 405-408, 2005.

SUDAWAN, B.; CHANG, C. S.; CHAO, H.; KU, M. S. B.; YEN, Y. Hydrogen cyanamide breaks grapevine bud 
dormancy in the summer through transient activation of gene expression and accumulation of reactive oxygen and nitrogen species. BMC Plant Biology, Londres, v. 16, n. 1, p. 202-203, 2016. DOI: 10.1186/s12870-0160889-y

UBER, S. C.; PETRI, J. L.; FAGUNDES, E.; COUTO, M.; FRANCESCATTO, P.; ESPERANÇA, C. F. Eficiência do $\operatorname{erger}{ }^{\circledR}$ como indutor de brotação em alternativa a cianamida hidrogenada. Revista da Jornada de Pós-Graduação e Pesquisa - Congrega, Bagé, v. 14, n. 1, p. 1451-1466, 2017.

VELIKOVA, V.; YORDANOV, I.; EDREVA, A. Oxidative stress and some antioxidant systems in acid rain-treated bean plants: protective role of exogenous polyamines. Plant Science, Limerick, v. 151, n. 1, p. 5966, 2000. DOI: 10.1016/S0168-9452(99)00197-1 
